\title{
Seabird community structure in a coastal tropical environment: importance of natural factors and fish aggregating devices (FADs)
}

\author{
Sébastien Jaquemet ${ }^{1, *}$, Matthieu Le Corre ${ }^{1}$, Henri Weimerskirch ${ }^{2}$ \\ ${ }^{1}$ Laboratoire ECOMAR, Université de La Réunion, 15, Avenue René Cassin, BP 7151, 97715 Saint Denis Message Cedex, \\ Ile de La Réunion, France \\ ${ }^{2}$ Institut de Recherche pour le Développement-La Réunion, BP 172, 97492 Ste Clotilde, Ile de la Réunion, France
}

\begin{abstract}
In tropical waters, productivity is low and seabirds only feed at the surface, often in association with sub-surface predators. We studied the distribution and abundance of seabirds in the coastal marine environment around Réunion Island, SW Indian Ocean, between February 2001 and October 2002. We investigated the distribution and abundance of birds at sea with respect to the effects of natural factors, such as bathymetry, distance to the shore, season and associations with subsurface predatory schools, and the presence of anchored fish aggregating devices (FADs). A total of 13572 birds of 15 species were observed, 8 of which were rare. Among the 7 abundant species, lesser noddies appeared to favour the shelf area. Barau's petrels and sooty terns were more abundant offshore, and wedge-tailed shearwaters, Audubon's shearwaters, white-tailed tropicbirds and brown noddies were present over all habitats. When foraging, most species searched for prey solitarily or in very small groups. When feeding, they were generally in large multi-species flocks, especially when feeding events occurred in association with sub-surface predatory schools. Associations with surfacefeeding schools of tunas, mainly skipjack, increased the abundance of most seabird species that fed on small fish or squids. The notable exception was for the white-tailed tropicbird, which was rarely found in association with sub-surface predators and, when associated, preferentially selected dolphin pods rather than tuna schools. Although they were often associated with tuna schools, lesser noddies were also strongly concentrated on the shelf, feeding on small pelagic schools. While the aggregating power of FADs on pelagic fish has previously been demonstrated, the associations between schools of sub-surface predators and seabirds were not more frequent close to FADs. However, 2 seabird species were more abundant close to FADs when feeding, and 1 when foraging, suggesting that they may occasionally take advantage of the attractive power of FADs. Seasonal variations in the occurrence of associations indicated a turn-over of fish species that induced variations in the nature of the associations, with the greatest aggregating power of dolphin fish in spring during their peak of abundance in the vicinity of the island.
\end{abstract}

KEY WORDS: Seabird · Association · Pelagic fish · FAD · Tropical Indian Ocean · Réunion Island Resale or republication not permitted without written consent of the publisher

\section{INTRODUCTION}

Studies of the seabird distribution have shown that birds are not uniformly distributed over their oceanic habitats (Ashmole 1971, Hunt 1990, Hunt et al. 1999). This patchiness is frequently associated with physical processes that vary in spatial scale, from small features such as Langmuir cells to fronts and major ocean cur- rents (Hunt \& Schneider 1987). Those hydrographic structures, through various mechanisms, tend to concentrate marine organisms near the surface by direct transport or by inducing favourable conditions for their growth. Thus, patches of prey are made locally and temporarily more available for seabirds. As a consequence, the distribution and abundance of seabirds are often related to specific marine habitat and usually 
reflect the availability of prey on which they rely (Hunt 1991). Many previous studies have described the strong spatial association between seabirds and their prey at different scales, in various oceanic habitats worldwide (e.g. Schneider \& Piatt 1986, Hunt et al. 1988, Veit \& Hunt 1992, Parrish et al. 1998, Raya Rey \& Schiavini 2000).

In tropical areas, where productivity is generally low, seabirds tend also to concentrate over productive areas where prey are more abundant and/or more easy to catch (e.g. Ribic et al. 1997a, Mills 1998). The distribution of those prey patches depends on physical parameters like thermal fronts (Pocklington 1979, Ribic \& Ainley 1997, Spear et al. 2001), upwellings (Hayes \& Baker 1989), currents (Haney 1986) or salinity gradients (Ribic et al. 1997a). However, because tropical deep blue waters are more homogeneous and less productive than other oceanic areas, patches of prey available for seabirds are rare and unpredictably distributed (Ballance et al. 1997). In this poor environment, the presence of large schools of surface-dwelling predatory fishes or marine mammals plays a major role in the availability of prey (Ashmole \& Ashmole 1967, Harrison et al. 1983, Au \& Pitman 1986, Ballance \& Pitman 1992, Ribic et al. 1997b, Bräger 1998, Clua \& Grosvalet 2001). By driving their prey to the surface, predators make them accessible to seabirds (Ashmole \& Ashmole 1967). This association is common in tropical areas, and some seabird species are even regarded as 'near-obligate commensals' of surface-dwelling tunas (Au \& Pitman 1986). Thus, seabirds are frequently used as indicators of fish schools, the most common example being the use of seabird radar by purse-seine vessels to detect schools of surface tunas (Marsac 1992a). Another common way to increase yields for fisheries is to exploit the natural tendency of predatory fishes to gather beneath floating objects (see Fonteneau 2000, Fréon \& Dagorn 2000). Nowadays, numerous drifting and anchored fish aggregating devices (FADs) are used in various parts of the world, and most of the catches of tunas in tropical areas are made with such devices near-shore and offshore (e.g. Fonteneau 2000, Holland et al. 2000, Kakuma 2000).

Most studies on the distribution and abundance of tropical seabirds have focused over the oceanic waters of the Pacific Ocean (Ashmole 1971, Au \& Pitman 1986, Ballance \& Pitman 1992, Ballance et al. 1997, Spear et al. 2001). Moreover, interactions between seabirds and surface fish schools or marine mammal groups over the coastal areas were rarely investigated (but see Hayes \& Baker 1989). In the Indian Ocean, Réunion Island is the breeding place of 6 seabird species, among which 2 are endemic threatened species, Barau's petrel Pterodroma baraui and Mascarene petrel Pseudobulweria atterima (Barré et al. 1996). Vagrant and migrant seabirds can also frequently be observed off the island periodically (Barré et al. 1996). Off Réunion Island, the tuna fishing activity has increased since the early 1990's with the deployment of 27 FADs between 5 and $12 \mathrm{~nm}$ from the shore to improve the catch per unit effort (CPUE) of local non-industrial fishermen (Tessier et al. 2000). The impact of FADs on tuna distribution (Conand 1995, Marsac \& Cayré 1998) and on fishing yields (Tessier \& Poisson 1997, Tessier et al. 2000) has been investigated locally, but no study has been conducted on the potential impact of FADs on other marine organisms. However, although fishermen traditionally use seabirds to locate tuna schools, no study has attempted to evaluate the aggregating power of anchored FADs on tropical seabirds.

In this paper we tested the hypothesis that anchored FADs, by aggregating surface predators, may also influence distribution and abundance of foraging birds in the coastal environment. This hypothesis is of interest because under natural conditions, the spatial distribution of prey of seabirds is regarded as unpredictable, and both foraging and breeding strategies of tropical seabirds have been shaped partly by this unpredictability (Feare 1976, Balance \& Pitman 1999, Le Corre 2001). If FADs represented a predictable feeding site for seabirds, they could have important consequences on the feeding ecology and breeding success of tropical seabirds. Our aim was thus to test whether FADs have an attractive power on seabirds, and whether they represent a human-induced modification in the foraging strategy of the birds. For this purpose, we examined potential natural factors which could affect the distribution and abundance of seabirds around Réunion Island, such as season, distance to the shore, bathymetry and interactions with schools of subsurface predators together with the presence of FADs.

\section{MATERIALS AND METHODS}

Study area and data collection. Réunion Island $\left(21^{\circ} \mathrm{S}\right.$,

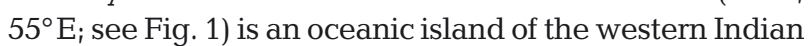
Ocean. Its continental shelf is very narrow, and coral reefs fringe less than $10 \%$ of the coastline. At 10 and $30 \mathrm{n}$ miles from the coast, the depth reaches 1500 and $3500 \mathrm{~m}$, respectively. The oceanic environment off Réunion is homogeneous, and this oceanic island is far from any upwelling. The trade winds blow south-westerly year round, and strengthen during the austral winter (June to August). Tropical storms, accompanied by violent wind and heavy rains, are very frequent during the austral summer (December to March), and have important effects on swell direction and strength. Sea surface waters are typically deep blue tropical waters with a very low productivity year round, and some local chlorophyll 


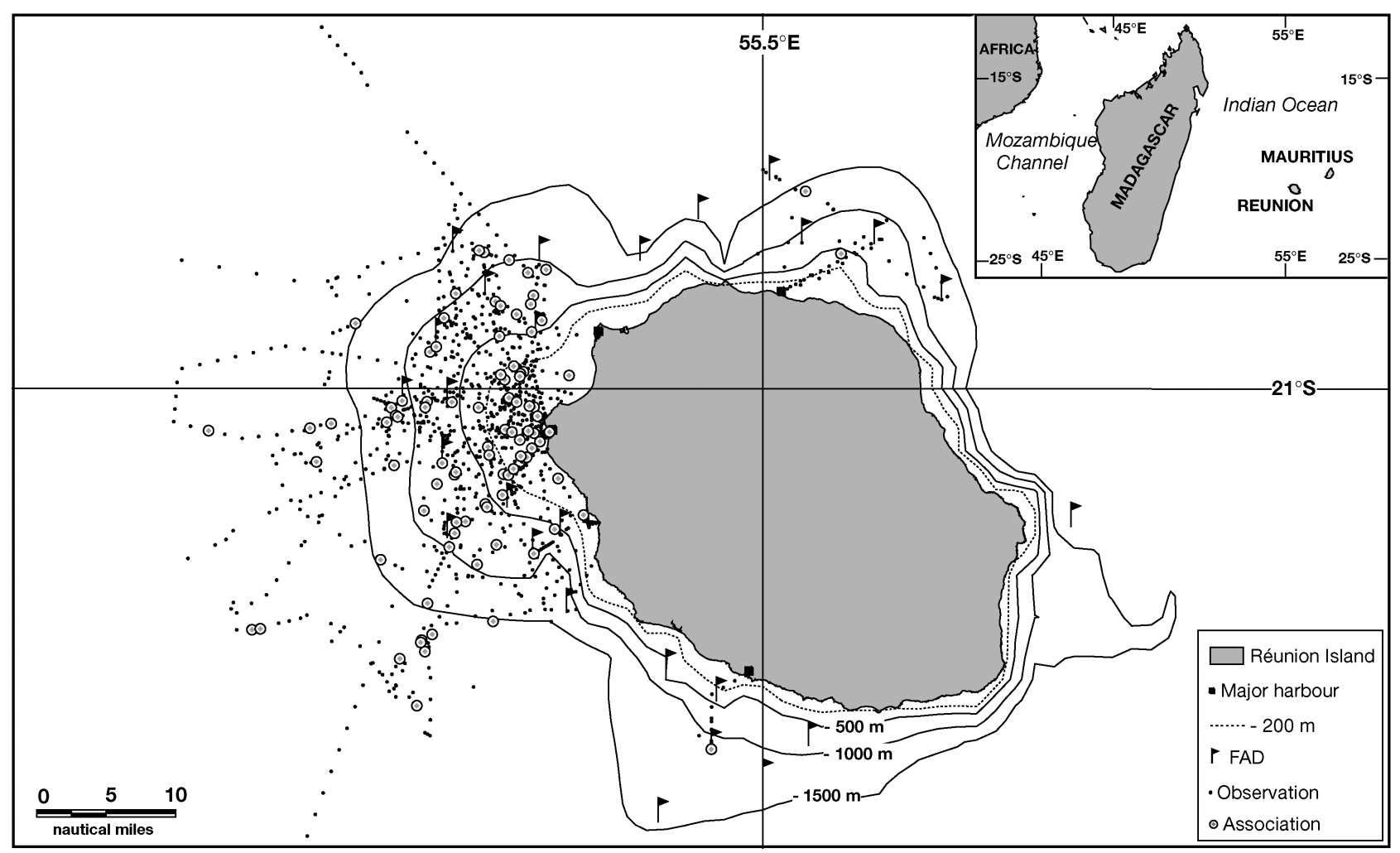

Fig. 1. Study area, with location of seabird observations and associations with sub-surface predatory schools. FAD: fish aggregating device

peaks induced by upwelled waters at the divergence of different water masses (Piton \& Taquet 1992). The thermocline is deep (100 $\mathrm{m}$ on average, Marsac 1992b), and the sea surface temperature averages $28^{\circ} \mathrm{C}$ during austral summer and $23^{\circ} \mathrm{C}$ during winter. The salinity averages 35 PSU year round (Piton \& Taquet 1992).

The study was carried out from February 2001 to October 2002 in an area extending from shore to $30 \mathrm{n}$ miles (Fig. 1). This study area includes all the FADs anchored around Réunion Island. Seabird data were collected monthly during $31 \mathrm{~d}$ trips and $5 \mathrm{~d}$ of cruise surveys from game fishing boats or longliners chartered by scientists. The mean speed of the ships was $15 \mathrm{~km} \mathrm{~h}^{-1}$ (8 knots). Most at-sea surveys were made on the leeward side (the west coast), where most of the FADs had been anchored (Fig. 1). All observations were made with $10 \times 50$ binoculars during daylight hours by 1 observer when the ship was travelling along radials. Seabirds were counted continuously along band transects of $300 \mathrm{~m}$ width from the boat, following Tasker et al. (1984), and sampling effort was performed to minimize replicated area during the same day. The width of $300 \mathrm{~m}$ from the boat was estimated at the beginning of the study using both the range finder method (Heinemann 1981) and the radar of the longliners. The band transects were then divided into periods of $10 \mathrm{~min}$ (Tasker et al. 1984). For each 10 min period, we recorded the local time, the GPS position and the number of birds of the different species observed. We also recorded the behaviour of birds (feeding, flying or sitting on water), and the presence of surface-dwelling fishes or mammals. Generally, schools of marine predators were found consecutively with seabird flocks, or sometimes with the sonar of the boat, and the identification of the species was carried out by direct observation when they jumped out of the water at the surface, or by fishing some individuals out. Using the GPS position of each 10 min period and the position of each FAD, we calculated the distance of each 10 min period to the nearest FAD.

Data analysis. For each species, we investigated the effects of season, presence of predatory fishes or mammals, distance to the shore, bathymetry and distance to the nearest FAD on the number of birds found per 10 min count. We also tested whether some seabird species showed specific associations with marine predators, and the frequency of the association according to the distance to the nearest FAD. Finally, the composition of the seabird feeding flocks was recorded according to the dominant species. Following Ballance 
et al. (1997), we defined a flock as any group of 5 or more birds. For each flock, the number of individuals of each species was recorded.

We considered 4 season classes of 3 mo each (Summer: December to February; Autumn: March to May; Winter: June to August; and Spring: September to November). We divided the bathymetry into 5 classes ( 0 to 200,200 to 500,500 to 1000,1000 to 1500 , and $>1500 \mathrm{~m}$ ) and distance to the shore into 6 equal classes of $5 \mathrm{n}$ mile width, from the shore to $30 \mathrm{n}$ miles. Finally, distances to the nearest FAD were separated into 4 classes ( 0 to 1,1 to 2,2 to 5 , and $>5 \mathrm{n}$ miles). Each observation was allocated to a class for all categorical variables using the GIS software MapInfo (MapInfo 1999), using standard query language (SQL) request. Abundances of seabird species were modelled as a function of the different considered variables. Generalized linear models, with a Poisson distribution of the data, were performed on the number of seabirds per 10 min period, with the aim of determining which factors best explain the variability observed in the abundance of seabirds in the study area. For each species, we tested the most complete model, then we deleted non-significant factors to get the most parsimonious model with the best goodness-of-fit statistic for the data. All computations were performed with S-PLUS software (2001). Association between birds and marine predators and frequency of association according to the distance to the FAD were tested using chi-square tests with STATISTICA software (Statsoft 1995), and statistical significance was assumed for $\mathrm{p}<0.05$.

\section{RESULTS}

We recorded 13572 birds of 15 species during the $1185 \times 10 \mathrm{~min}$ periods of observations made around Réunion Island. Among these species, 8 were rarely sighted and each of them contributed less than $1 \%$ of all observations, with a maximum of 10 individuals recorded during the study (Table 1 ).

Brown noddies were the most frequently observed and the most abundant in the area, representing $27 \%$ of all observations (Table 1). The 2 shearwater species were also abundant, and occurred in more than $20 \%$ of all the $10 \mathrm{~min}$ periods. Lesser noddies, Barau's petrels and white-tailed tropicbirds occurred in more than $10 \%$ of the 10 min periods, and also in an average of $10 \%$ of observations (Table 1 ). However, lesser noddies were clearly more abundant than Barau's petrels and white-tailed tropicbirds. Sooty terns occurred in fewer observations but were more abun-

Table 1. Number of observations, number of individuals, occurrence, mean $( \pm \mathrm{SD})$ number of individuals per 10 min period, mean $( \pm \mathrm{SD})$ number of individuals per observation according to their activity by seabird species. Réunion breeders in bold

\begin{tabular}{|c|c|c|c|c|c|c|c|c|}
\hline \multirow[t]{3}{*}{ Species } & \multicolumn{2}{|c|}{ Observations } & \multicolumn{2}{|c|}{ Individuals } & \multirow{3}{*}{$\begin{array}{c}\text { Occurrence } \\
\%\end{array}$} & \multirow{3}{*}{$\begin{array}{l}\text { Mean no. } \\
\text { birds per } \\
10 \text { min }\end{array}$} & \multirow{2}{*}{\multicolumn{2}{|c|}{$\begin{array}{l}\text { Mean no. birds } \\
\text { per observation }\end{array}$}} \\
\hline & $\mathrm{n}$ & $\%$ & $\mathrm{n}$ & $\%$ & & & & \\
\hline & & & & & & & Feeding & Others \\
\hline $\begin{array}{l}\text { Brown noddy } \\
\text { Anous stolidus }\end{array}$ & 396 & 26.6 & 5736 & 42.29 & 33.4 & $4.8 \pm 18.8$ & $44.6 \pm 9.4$ & $4.3 \pm 7.8$ \\
\hline $\begin{array}{l}\text { Audubon's shearwater } \\
\text { Puffinus lhierminieri bailloni }\end{array}$ & 255 & 17.2 & 1573 & 11.59 & 21.5 & $1.3 \pm 6.5$ & $15.9 \pm 4.2$ & $2.2 \pm 2.9$ \\
\hline $\begin{array}{l}\text { Wedge-tailed shearwater } \\
\text { Puffinus pacificus }\end{array}$ & 240 & 16.2 & 1599 & 11.78 & 20.3 & $1.3 \pm 11.8$ & $23.2 \pm 15.8$ & $2.7 \pm 5.3$ \\
\hline $\begin{array}{l}\text { White-tailed tropicbird } \\
\text { Phaethon lepturus }\end{array}$ & 174 & 11.7 & 238 & 1.75 & 14.7 & $0.2 \pm 0.6$ & $1.7 \pm 0.5$ & $1.3 \pm 0.6$ \\
\hline $\begin{array}{l}\text { Barau's petrel } \\
\text { Pterodroma baraui }\end{array}$ & 150 & 10.1 & 402 & 2.96 & 12.7 & $0.3 \pm 1.3$ & $4.8 \pm 1.6$ & $2.2 \pm 1.9$ \\
\hline $\begin{array}{l}\text { Lesser noddy } \\
\text { Anous tenuirostris }\end{array}$ & 131 & 8.8 & 3179 & 23.42 & 11.1 & $2.7 \pm 19.1$ & $49.5 \pm 19.2$ & $5.4 \pm 8.1$ \\
\hline Sooty tern Sterna fuscata & 104 & 7 & 802 & 5.91 & 8.8 & $0.7 \pm 5.1$ & $21.9 \pm 8.9$ & $2.4 \pm 2.8$ \\
\hline $\begin{array}{l}\text { Brown skua } \\
\text { Catharacta lonnbergi }\end{array}$ & 10 & 0.7 & 10 & 0.07 & 0.8 & $0.01 \pm 0.1$ & & 1 \\
\hline $\begin{array}{l}\text { Mascarene petrel } \\
\text { Pseudobulweria aterrima }\end{array}$ & 7 & 0.5 & 7 & 0.05 & 0.6 & $0.006 \pm 0.08$ & & 1 \\
\hline $\begin{array}{l}\text { Pomarine skua } \\
\text { Stercorarius pomarinus }\end{array}$ & 6 & 0.4 & 9 & 0.07 & 0.5 & $0.008 \pm 0.1$ & & $1.5 \pm 0.8$ \\
\hline Tern Sterna sp. & 4 & 0.3 & 6 & 0.04 & 0.3 & $0.05 \pm 0.09$ & & $1.5 \pm 0.6$ \\
\hline Prion Pachyptila sp. & 3 & 0.2 & 3 & 0.02 & 0.3 & $0.002 \pm 0.05$ & & 1 \\
\hline $\begin{array}{l}\text { Black-bellied storm petrel } \\
\text { Fregetta tropica }\end{array}$ & 2 & 0.1 & 4 & 0.03 & 0.2 & 0.003 & & $2 \pm 1.4$ \\
\hline $\begin{array}{l}\text { Bulwer's petrel } \\
\text { Bulweria bulweri }\end{array}$ & 2 & 0.1 & 2 & 0.01 & 0.2 & 0.001 & & 1 \\
\hline $\begin{array}{l}\text { Wilson's storm petrel } \\
\text { Oceanites oceanicus }\end{array}$ & 2 & 0.1 & 2 & 0.01 & 0.2 & 0.001 & & 1 \\
\hline
\end{tabular}


Table 2. Results of the generalized linear models testing the influence of various factors on the abundance of 7 seabird species. Variables contributing to most of the deviance are in bold. df: degrees of freedom, * : interaction terms. See Table 1 for species names

\begin{tabular}{|c|c|c|c|c|c|}
\hline Species & Model & Null deviance & $\mathrm{df}$ & Residual deviance & df \\
\hline Brown noddy & Season + Association + Season ${ }^{*}$ Association & 25623 & 1184 & 11580 & 1170 \\
\hline $\begin{array}{l}\text { Audubon's } \\
\text { shearwater }\end{array}$ & $\begin{array}{l}\text { Season + Bathymetry + Association + } \\
\text { Season * Association }\end{array}$ & 8013 & 1184 & 4428 & 1166 \\
\hline Lesser noddy & $\begin{array}{l}\text { Season + FAD + Dist. to the shore + } \\
\text { Association + Season }{ }^{*} \text { FAD }\end{array}$ & 20878 & 1184 & 10738 & 1162 \\
\hline $\begin{array}{l}\text { White-tailed } \\
\text { tropicbird }\end{array}$ & $\begin{array}{l}\text { Bathymetry + Association + } \\
\text { Bathymetry * Association }\end{array}$ & 880 & 1184 & 856 & 1165 \\
\hline $\begin{array}{l}\text { Wedge-tailed } \\
\text { shearwater }\end{array}$ & $\begin{array}{l}\text { Season + FAD + Bathymetry + Dist. to the shore + } \\
\text { Association + Association * Bathymetry }\end{array}$ & 9962 & 1184 & 3805 & 1154 \\
\hline Sooty tern & $\begin{array}{l}\text { Season + FAD + Bathymetry + Association + } \\
\text { FAD * Association }\end{array}$ & 5574 & 1184 & 2320 & 1162 \\
\hline Barau's petrel & $\begin{array}{l}\text { Season + FAD + Bathymetry + Dist. to the shore + } \\
\text { Season * FAD }\end{array}$ & 1936 & 1184 & 1205 & 1161 \\
\hline
\end{tabular}

dant per observation than Barau's petrels and whitetailed tropicbirds.

The average number of birds per observation was very different according to species and activity (Table 1). All species were significantly more abundant when feeding (Mann-Whitney test, $\mathrm{p}<0.01$ for all species) than when foraging. The 2 noddies were the most abundant per observation of all feeding birds. Sooty terns, wedge-tailed shearwaters and Audubon's shearwaters were more than 2 times less abundant in feeding flocks than noddies (Table 1). Finally, Barau's petrels and white-tailed tropicbirds were observed with few other seabirds, even when feeding.

Table 2 gives results of the most parsimonious model selected for the main seabird species with the best goodness-of-fit. High residual deviance indicates that these models explain only a small part of the variance for most of the species. Moreover, most of the models show an overdispersion of the data. However, all selected factors in each model have a significant effect ( $p<5 \%$ for all), and the analysis indicates that associations with schools of sub-surface predators was the variable explaining the most deviance of the models, except for Barau's petrel, for which the season explained most.

\section{Effects of bathymetry and distance to the shore}

Both bathymetry and distance to the shore influenced the abundance of birds, and effects were different according to species. Brown noddies were not significantly affected by depth and distance to the shore (Table 2). Lesser noddies were mainly associated with the shelf, and their abundance decreased significantly with distance and depth (Fig. 2). White-tailed tropic-

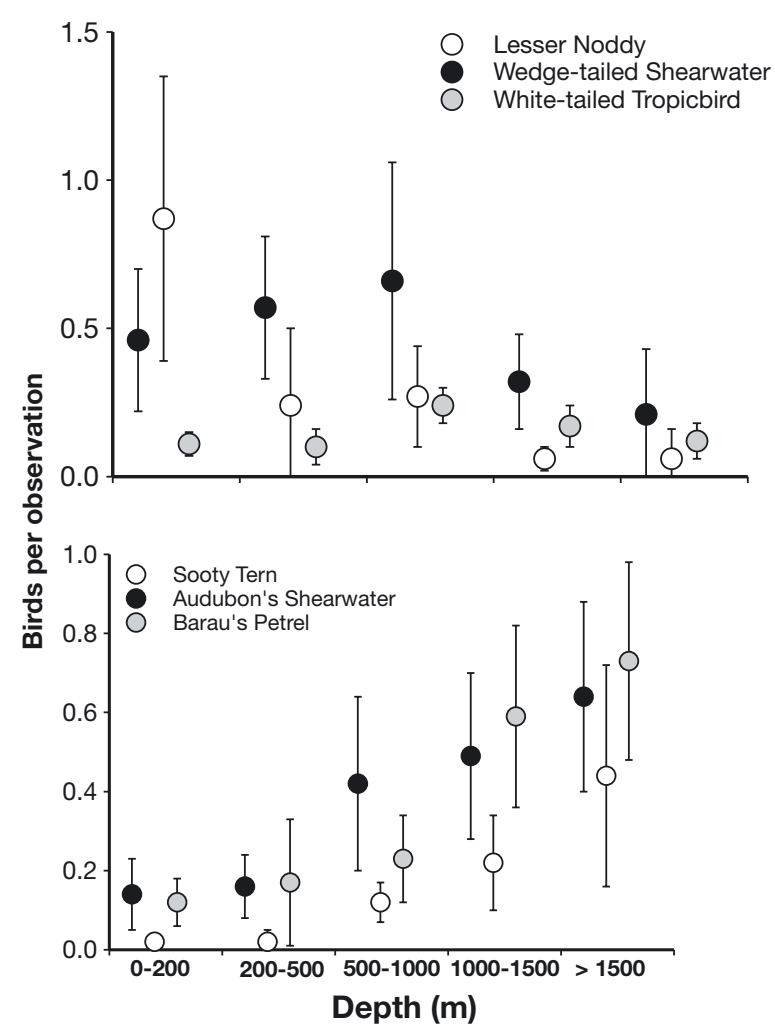

Fig. 2. Mean number of flying birds $( \pm \mathrm{SE})$ per $10 \mathrm{~min}$ period over depth classes. See Table 1 for species names

birds and wedge-tailed shearwaters were present in all the areas, with a highest abundance in the 500 to $1000 \mathrm{~m}$ depth class. Finally, sooty terns, Audubon's shearwaters and Barau's petrels showed a more pelagic distribution, as indicated by the significant increase of their abundance from inshore to offshore (Fig. 2). 


\section{Seasonality of abundance}

The abundance of all species differed according to the seasons (Fig. 3). White-tailed tropicbirds breed all year round on Réunion but were more abundant between December and February during their peak of reproduction. Brown noddies breed, and were observed, all year
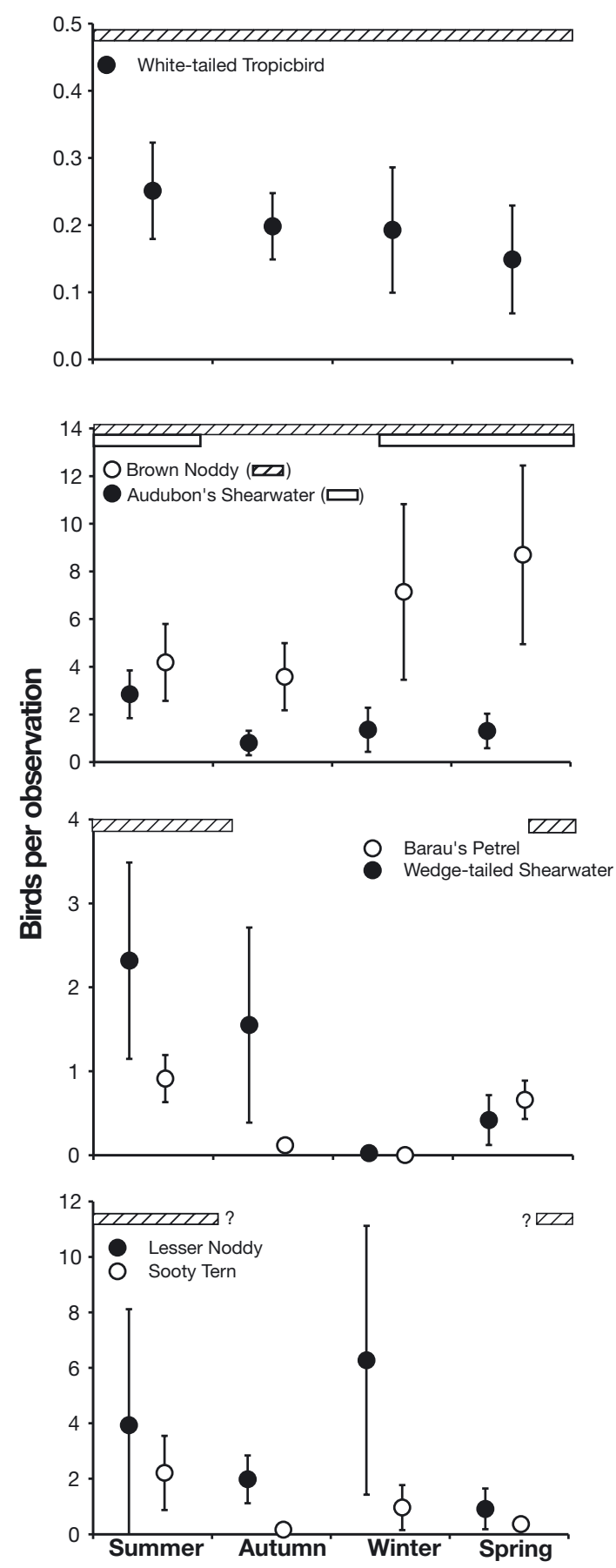

Fig. 3. Mean number of birds $( \pm \mathrm{SE})$ per $10 \mathrm{~min}$ period according to season. Breeding period is indicated by box blocks. See Table 1 for species names round, with highest abundance in winter. Barau's petrels and wedge-tailed shearwaters are summer breeders and were absent in winter. Audubon's shearwaters breed between July and February, while their abundance at sea peaked in summer. Sooty terns and lesser noddies breed on Mauritius Island (200 km from Réunion), probably in summer (S. J. pers. obs.), and numbers peaked around Réunion in summer and winter.

\section{Association with sub-surface predators}

Number of birds per 10 min peaked significantly with the presence of marine sub-surface predators, except for Barau's petrels (Table 2). All species were more abun-
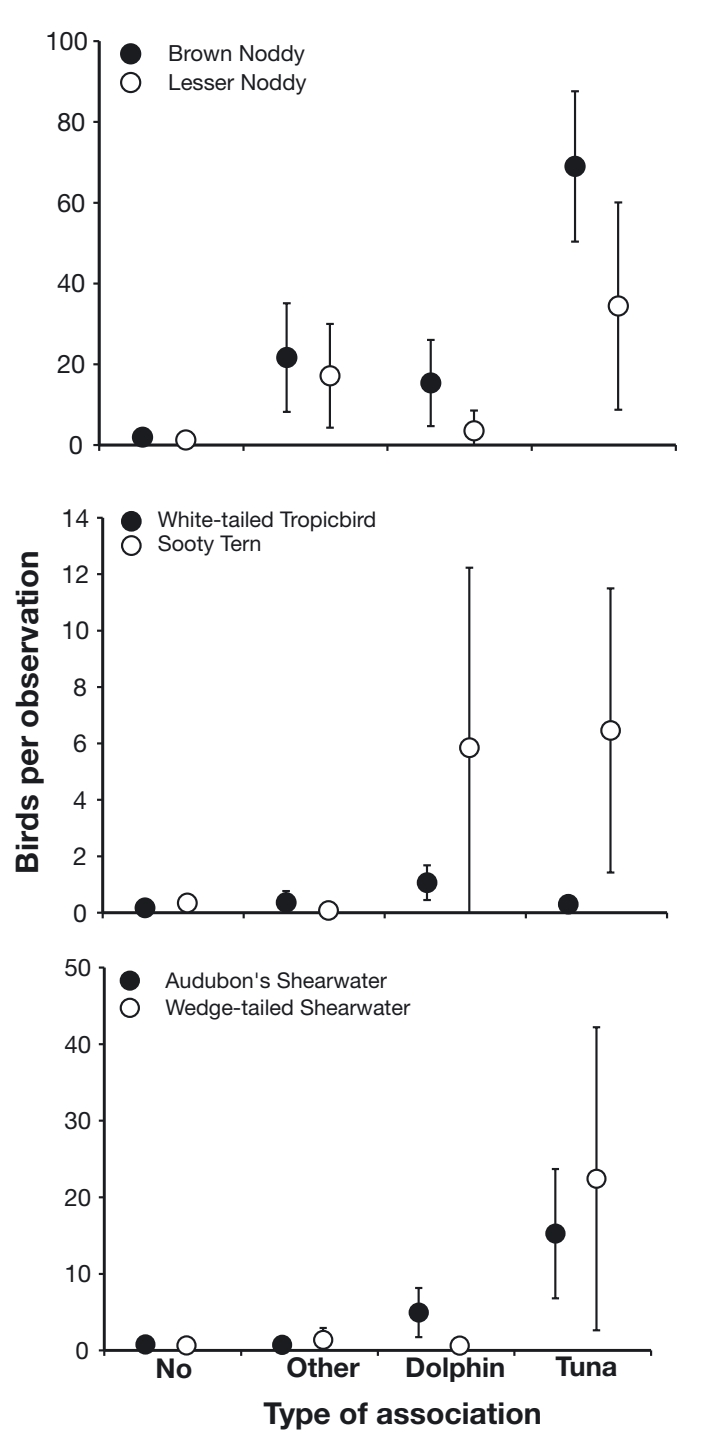

Fig. 4. Mean number of birds $( \pm \mathrm{SE})$ per $10 \mathrm{~min}$ period in relation to type of association. 'Other' category corresponds to other pelagic fish. See Table 1 for species names 
Table 3. Seabird feeding-flock characteristics and compositions according to the dominant species. See Table 1 for species names

\begin{tabular}{|c|c|c|c|c|c|c|c|}
\hline & $\begin{array}{l}\text { Brown } \\
\text { noddy }\end{array}$ & $\begin{array}{l}\text { Audubon's } \\
\text { shearwater }\end{array}$ & $\begin{array}{l}\text { Lesser } \\
\text { noddy }\end{array}$ & $\begin{array}{l}\text { White-tailed } \\
\text { tropicbird }\end{array}$ & $\begin{array}{l}\text { Wedge-tailed } \\
\text { shearwater }\end{array}$ & $\begin{array}{l}\text { Sooty } \\
\text { tern }\end{array}$ & $\begin{array}{l}\text { Barau's } \\
\text { petrel }\end{array}$ \\
\hline No. of flocks (association) & $62(39)$ & $10(4)$ & $27(13)$ & $1(1)$ & $5(4)$ & $4(2)$ & $2(2)$ \\
\hline Mean $( \pm \mathrm{SD})$ flock size & $119 \pm 84$ & $45 \pm 28$ & $106 \pm 124$ & 16 & $129 \pm 176$ & $126 \pm 37$ & 19 \\
\hline $\begin{array}{l}\text { Mean number }( \pm S D) \text { of individ- } \\
\text { uals of the dominant species }\end{array}$ & $61 \pm 53$ & $24 \pm 15$ & $82 \pm 94$ & 9 & $96 \pm 143$ & $63 \pm 29$ & 10 \\
\hline$\%$ of monospecific flocks & 8 & 0 & 26 & 0 & 20 & 0 & 0 \\
\hline \multicolumn{8}{|c|}{$\%$ of flocks including (in association): } \\
\hline Brown noddy & & $70(100)$ & $70(69)$ & $100(100)$ & $80(100)$ & $100(100)$ & 0 \\
\hline Audubon's shearwater & $71(74)$ & & $30(23)$ & $100(100)$ & $60(75)$ & $100(100)$ & $100(100)$ \\
\hline Lesser noddy & $40(49)$ & 30 & & 0 & 0 & 0 & 50 \\
\hline White-tailed tropicbird & $21(23)$ & 30 & $22(15)$ & & $20(25)$ & 25 & 0 \\
\hline Wedge-tailed shearwater & $42(38)$ & $40(50)$ & $30(31)$ & 0 & & 25 & 50 \\
\hline Sooty tern & $37(43)$ & $30(25)$ & 0 & 0 & 0 & & $50(100)$ \\
\hline Barau's petrel & $21(18)$ & $50(25)$ & $7(15)$ & 0 & 0 & $75(100)$ & \\
\hline
\end{tabular}

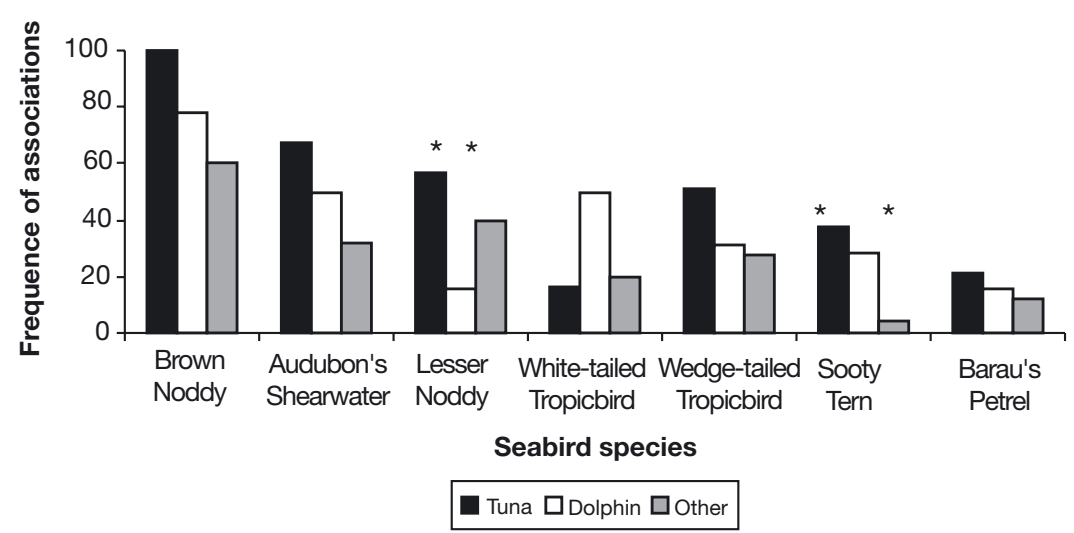

Fig. 5. Percentage of total associations with sub-surface predators per seabird species. *: Significant difference in the frequency of association. See Table 1 for species names

dant in multispecies feeding flocks when associated with sub-surface predators, and were otherwise observed solitarily or in very small groups when there was no association or feeding activity (Table 1, Fig. 4). Flocks dominated by brown noddies were the most abundant and more frequently associated with other seabird species, excepted with Barau's petrels (Table 3). Audubon's shearwaters were observed feeding in association with all species. Lesser noddies were never feeding with sooty terns and very few with Barau's petrels. Sizes of the feeding flocks were the largest when sooty terns, wedge-tailed shearwaters, lesser and brown noddies were the dominant species (Table 3).

The following associations between seabirds and sub-surface predators were observed: 37 with schools of surface tunas (skipjack tuna Katsuwanus pelamis, 92\%, and yellowfin tuna Thunnus albacares, 8\%), 32 with pods of dolphins (mostly spinner dolphin Stenella longirostris, spotted dolphins S. attenuata, common dolphin Delphinus delphis, bottlenose dol- phin Tursiops truncatus, and other unidentified species) and 25 with other various schools of fish and pods of mammals (dolphinfish Coryphaena hippurus, $40 \%$, small Carangid-like Decapterus sp., Selar sp., $28 \%$, and various other species). Five percent were mixed tuna/dolphin schools: we attributed these schools to a category of association according to the dominant species. Finally, $3 \%$ of schools of fish or pods of dolphins were recorded without any seabirds. Brown noddies were observed in all flocks feeding with tuna schools (Fig. 5). The frequency of occurrence of most species was higher for associations with tuna than with dolphins and other predators (Fig. 5). However, white-tailed tropicbirds often fed without any association, and when associated, tended to be more attracted by dolphins than by tunas and others predators $\left(\chi^{2}=5.6 ; \mathrm{df}=2 ; \mathrm{p}=0.059\right)$. Lesser noddies and sooty terns favoured tunas rather than dolphins $\left(\chi^{2}=4.8 ; \mathrm{df}=1 ; \mathrm{p}=0.029\right)$ or other fishes $\left(\chi^{2}=4.7 ; \mathrm{df}=1 ; \mathrm{p}=0.03\right)$, respectively. Wedge-tailed and Audubon's shearwaters, brown and lesser noddies were significantly more numerous per flock when associations occurred with surface tunas, whereas white-tailed tropicbirds were more abundant in association with dolphins (Fig. 4). Sooty terns were more frequently associated with tunas than with dolphins, but number of individuals per flocks did not show any significant difference.

Seasonality of the association gives more precise details on specific relationships between seabirds and marine predatory organisms and seasonal presence of those predators around Réunion Island. Associations with tunas and dolphins occurred year round, whereas 


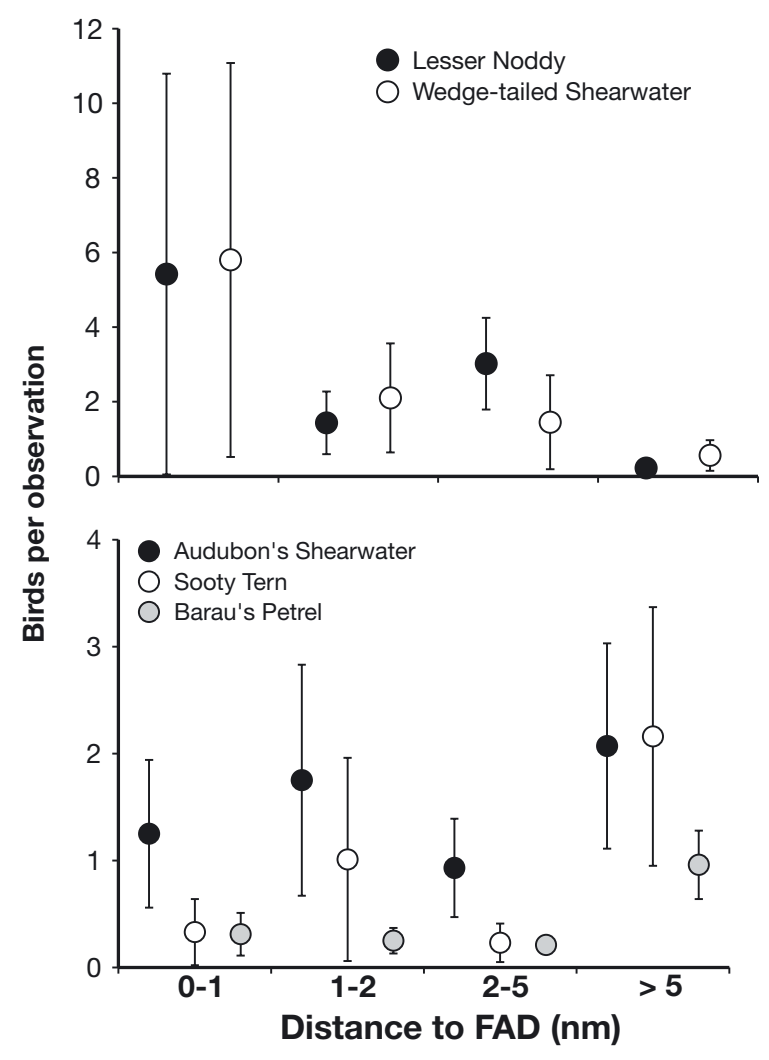

Fig. 6. Mean number of foraging birds $( \pm \mathrm{SE})$ per $10 \mathrm{~min}$ period over the distance to the nearest fish aggregating device (FAD) classes. See Table 1 for species names

associations with other fish occurred mainly in spring and autumn (only 1 was observed in summer, and none in winter). In autumn, lesser noddies were preferentially associated with schools of small pelagic fish rather than with all other marine predators (KruskalWallis test $H_{5,640}=77.3 ; \mathrm{p}<0.001$ ) and the number of birds per flock was on average 1.5 times higher than when associated with tunas $(15.3 \pm 9.9)$, and more than 13 times higher compared with dolphins $(1.8 \pm 3.4)$. In spring, dolphinfish were the only 'other' type of association, and numbers of brown noddies associated with dolphinfish schools were as abundant as in flocks associated with tunas or dolphins during that season (Mann-Whitney $U=27$; $>0.2$ for tunas, and $U=13$; $\mathrm{p}>0.3$ for dolphins). In winter, numbers of individuals per flock associated with tuna schools and dolphins pods were not significantly different for brown noddies (Mann-Whitney $U=18 ; \mathrm{p}>0.7$ ), Audubon shearwaters (Mann-Whitney $U=19$; p > 0.8), white-tailed tropicbirds (Mann-Whitney $U=16 ; \mathrm{p}>0.5$ ) and sooty terns (Mann-Whitney $U=12 ; \mathrm{p}>0.2$ ). Finally, white-tailed tropicbird abundance in spring showed no significant difference, whether they were associated with predators or not (Kruskal-Wallis test $H_{3,182}=1.7$; $p>0.6$ ), and were never observed with tuna schools.

\section{Impact of FADs}

In the proximity of FADs ( $<1 \mathrm{n}$ miles), the abundance of foraging wedge-tailed shearwaters was higher than at more distant locations, whereas Barau's petrels, sooty terns and Audubon's shearwaters showed the reverse pattern (Fig. 6). When feeding, lesser noddies (Kruskal-Wallis test $H_{3,1185}=16.03 ; \mathrm{p}=0.0011$ ) and wedge-tailed shearwaters (Kruskal-Wallis test $H_{3,1185}=$ 18.20; $\mathrm{p}=0.0004$ ) were more abundant at close range from the FADs, whereas Barau's petrel were more abundant far from the FADs. Sooty terns and Audubon's shearwaters showed the same patterns of distribution in the classes of distance to the nearest FAD, and were not more abundant in the vicinity of the devices. The distance to FADs was not a factor clearly affecting the abundance of foraging and feeding brown noddies and white-tailed tropicbirds (Table 2). Finally, the proximity of the FADs did not affect the occurrence of associations $\left(\chi^{2}\right.$-test, $p>0.05$ for all species and all types of association).

\section{DISCUSSION}

Our study shows that the seabird community around Réunion Island is strongly structured according to distance to the shore and bathymetry. It also highlights that, even in the vicinity of an island, in the Indian Ocean the presence of sub-surface predator groups, especially tunas and to a lesser extent dolphins, provides the major feeding opportunity for tropical seabirds.

\section{The seabird community around Réunion Island}

Seabirds sighted in the vicinity of Reunion Island are divided into 2 groups, rare species and the more abundant ones on which the study focused. The rare species breed mainly south of the subtropical convergence (Barré et al. 1996) and most of them are known to disperse in the open ocean during their non-breeding period (Harrison 1983, Van Den Berg et al. 1990). The notable exception is the endemic Mascarene petrel Pseudobulweria aterrima, which breeds on Réunion and is one of the most threatened seabirds in the world (Barré et al. 1996, Le Corre et al. 2003a).

For most of the Réunion breeders, annual variations in abundance were related to their breeding phenology. The summer breeders, Barau's petrels and wedge-tailed shearwaters were totally absent from the study area during winter; Stahl \& Bartle (1991) have previously described Barau's petrel as a migratory species. The 2 species are known to disperse throughout the Indian Ocean during austral winter, particularly 
north of the Equator, where summer conditions occur with high sea surface temperature (Pocklington 1979, Van Den Berg et al. 1990). Although they breed year round, white-tailed tropicbirds were more abundant in summer around Réunion Island during their peak of reproduction, when optimal environmental conditions probably occurred. Indeed, this species favours warm sea surface temperature $\left(>27.5^{\circ} \mathrm{C}\right)$ and lower salinity (<35.4 PSU) (Pocklington 1979). Sooty terns and lesser noddies probably breed annually on Mauritius Island, but their abundance in the vicinity of Réunion Island peaks in summer and winter. It was not possible to determine their breeding status. Sooty terns are very pelagic birds, with a wide feeding range during the breeding period (Flint 1991), with summer and winter reproduction occurring at various places in the SW Indian Ocean (Feare 1976, Le Corre 2001), and the species has extensive wintering migrations, especially the juveniles (Robertson 1969).

At the coarse scale of the study, seabirds were not randomly distributed. Although all species were observed in all classes of bathymetry and distance to the shore, the community tended to be structured according to a gradient from inshore to offshore. Lesser noddies were more abundant in the coastal area mainly associated with the shelf and the outer slope of the reef, as has been previously observed in the eastern sub-tropical Indian Ocean (Surman \& Wooller 2003) and in the tropical Pacific Ocean (Harrison \& Seki 1987, Hulsman 1988). Audubon's shearwaters, Barau's petrels and sooty terns showed the reverse pattern, with an offshore distribution, showing a pelagic habitat even when breeding. This is in agreement with previous studies for Barau's petrel (Stahl \& Bartle 1991) and for the sooty tern in the Pacific (Flint 1991) and the Indian Ocean (Surman \& Wooller 2003). White-tailed tropicbirds and wedge-tailed shearwaters were distributed throughout the study area, with a tendency to be more abundant at the depth corresponding to the FAD area (200 to $500 \mathrm{~m}$ ), whereas they have often been recorded in deeper areas (i.e. Pocklington 1979, Harrison \& Seki 1987, Stahl \& Bartle 1991). Finally, brown noddies were abundant in all habitats at the scale of the study.

\section{Foraging strategies and associations with sub-surface predators}

Off Réunion Island, most foraging birds appeared to search for feeding opportunities solitarily or in small flocks, with average numbers $\leq 6$ birds per $10 \mathrm{~min}$ count, i.e. representing very low densities, even in the proximity of breeding grounds. Birds were rarely observed feeding solitarily, and most feeding events were related to the presence of sub-surface predators. The results highlight the particular foraging strategy of most tropical seabirds, their high reliance on subsurface predators for feeding. Flock compositions were also the result of the feeding strategies of the species. Feeding flocks dominated by brown noddies were most abundant, and the individuals were often associated with other seabird species. The species could even be considered as 'catalyst' of the feeding events around Réunion Island, as already described for other species elsewhere (Hoffman et al. 1981, Mills 1998), especially in the associations with sub-surface predators. The most pelagic species, sooty terns, Barau's petrels and Audubon's shearwaters, fed together, preferentially in flocks, as was previously observed by Stahl \& Bartle (1991) in the south of Réunion Island. On the other hand, lesser noddies fed most frequently in monospecific flocks, especially in the near-shore area, when associated with small pelagic fish schools. Finally, white-tailed tropicbirds were least abundant in the multispecies flocks, thus confirming their solitary feeding strategy.

Association with sub-surface predators in tropical areas is the main way for seabirds to obtain a higher availability of prey (Ashmole 1971). Indeed, subsurface marine predators feeding at the surface firstly indicate aggregation of prey and secondly induce easier accessibility to these resources for seabirds. In the marine environment around Réunion Island, where there are typical tropical conditions, this situation also occurs. Associations with tuna schools were the most frequent, especially with skipjack as recorded in Hawaii (Harrison \& Seki 1987). All seabird species were more abundant in flocks associated with tuna schools than those with other sub-surface predators, except for white-tailed tropicbirds, which were found preferentially in association with dolphins. In the tropical Pacific, skipjack tuna favour deep thermoclines and less productive waters (Hida 1970, Au \& Pitman 1986) and are surface feeders (Harrison \& Seki 1987). Similar oceanic conditions occur around Réunion Island (Piton \& Taquet 1992, Marsac 1992b), and yellowfin tuna occur at depths $>50 \mathrm{~m}$ (Conand 1995, Marsac \& Cayré 1998) and tend to forage generally at greater depths than surface feeding skipjack tunas. It is thus not surprising that skipjack schools were abundant at the surface and were more frequently aggregating feeding seabirds than yellowfin tuna, even though yellowfin catches are 5 times more important than skipjack to the Réunion fishery (Tessier \& Poisson 1997).

The 2 noddies and wedge-tailed shearwaters were more abundant in flocks associated with tunas. Wedge-tailed shearwater abundance was particularly affected by the presence of tunas, possibly because tuna schools are much larger than the other sub- 
surface predator schools. Similarly, the number of wedge-tailed shearwater in mixed-species flocks increased markedly with the size of dolphin pods in the Pacific (Au \& Pitman 1986).

Bird/dolphin associations were also frequent around Réunion Island, and identified dolphin species were similar to those sighted in the south tropical and subtropical Pacific (Au \& Pitman 1986, Ballance \& Pitman 1992, Ballance et al. 1997). The higher frequency of associations with tunas compared to dolphins was also noted in the south and central tropical Pacific areas (Au \& Pitman 1986). However, in winter, flocks foraging in association with dolphins were of the same size as those feeding with tunas, suggesting that tunas were relatively less abundant in the area, as indicated by data on fishing activity around Réunion Island (Tessier \& Poisson 1997), and that seabirds search for other sources of feeding. White-tailed tropicbirds were very different from other seabirds, since they generally foraged solitarily, as mentioned by Ballance \& Pitman (1999), and favoured associations with dolphins rather than tunas. Their mean number per flock associated with dolphins was similar to that recorded for tropicbirds in the oceanic areas of the tropical Pacific by $\mathrm{Au}$ \& Pitman (1986), near-shore from the Galapagos Islands by Hayes \& Baker (1989) and with tunas south of Réunion Island by Stahl \& Bartle (1991).

Dolphinfish and small pelagic fish were the main other sub-surface predators inducing associations, and both are also known to aggregate seabirds in Hawaii (Harrison \& Seki 1987). The major difference between tunas and dolphins was the marked seasonal nature of the associations. Associations with dolphinfish were observed almost exclusively in spring, which corresponds to the main fishing season at Réunion Island (Tessier \& Poisson 1997).

Lesser noddies were mainly associated with schools of small pelagic fish (Carangidae) in autumn only, and mainly over the slope of the shelf. Small carangids like Decapterus sp. and Selar crumenophthalmus are caught by fishermen seasonally during winter at Réunion Island (M. Soria pers. comm.). In autumn only, schools of juveniles are present and it may be these schools which are searched for by lesser noddies. In Hawaii, Harrison \& Seki (1987) observed preferential associations between black noddies and schools of small near-shore fishes like carangids. Over the shelf of the Seychelles, associations between near-shore carangid schools and large flocks of feeding lesser noddies (>250 birds) were observed in March 2002 (authors' unpubl. data).

Finally, Barau's petrels showed no preferential type of association, except that they were never associated near-shore with small fishes. There were, on average, 5 individuals of this species in multispecies feeding flocks, a figure close to that previously mentioned by Stahl \& Bartle (1991), who recorded 8 individuals per flock farther south of Réunion Island, between 25 and $26^{\circ} \mathrm{S}$. This result confirms the solitary behaviour and the very pelagic habitat of the species.

The near-obligate association between most seabird species and sub-surface predators is probably related to both prey accessibility and prey size (Harrison \& Seki 1987, Ballance et al. 1997). Indeed, most seabirds encountered in the study are small species and feed only in a narrow layer just beneath the surface, as with most of the tropical seabirds (Ballance \& Pitman 1999). As a consequence, most of the species need to find prey very close to the surface, in size classes in relation to their own ingestion capacity. The main exception was on the wedge-tailed shearwaters and the Audubon's shearwaters, which can dive to more than $30 \mathrm{~m}$ (Burger 2001). In Hawaii, a high degree of overlap in diet and prey size between skipjack tunas and associated birds has been observed (Harrison et al. 1983, Harrison \& Seki 1987). The observation is strengthened by the particular association between lesser noddies, the smallest species, and the small carangid schools near the slope of the shelf, especially during early stages of development of those fishes when their prey are mostly juveniles of clupeids and pelagic post-larvae of reef fishes (Conand \& Roux 2000). Moreover, during the peak of abundance, dolphinfish are 1 yr old, with an average weight <10 kg (Tessier \& Poisson 1997). These fishes probably forage on smaller prey than adults, and consequently have a high aggregating potential for seabirds. The relationship between associations and prey size could also explain the preferential association between dolphins and tropicbirds that feed on larger prey than the other seabirds (Harrison et al. 1983, Harrison \& Seki 1987, Le Corre et al. 2003b).

\section{Impact of FADs on seabirds}

The potential aggregating power of anchored FADs on seabirds has never been tested. Arcos et al. (2000) reported observations of feeding Balearic shearwaters Puffinus mauretanicus occasionally associated with drifting objects during their breeding season. Conversely, the effects of FADs on pelagic fish have already been demonstrated in most tropical areas (Brock 1985, Holland et al. 1990, Cayré 1991, Marsac \& Cayré 1998, Josse et al. 1999), and several hypothesis have been proposed to explain this attraction, among which the meeting point hypothesis is an alternative to the trophic theory (Fréon \& Dagorn 2000). Nevertheless, the review of associated fishes has shown that juveniles of many species are recruited under floating objects, including FADs (Castro et al. 2002). Therefore, it could be 
expected that FADs have a positive effect on seabirds. Our study, however, demonstrated that only foraging wedge-tailed shearwaters and feeding lesser noddies and wedge-tailed shearwaters were significantly more abundant at close range from FADs. The attraction of these 2 species, which are largely more abundant when associated with tuna schools, could be a reflection of the potential presence of larger feeding schools at proximity from FADs, but not necessarily at the surface. Especially wedge-tailed shearwaters, which search mostly for large tuna schools, seem to modify their foraging behaviour according to the presence of the FADs, probably by spending more time in the vicinity of them. Indeed, their diving ability (Burger 2001) could allow them to reach schools of yellowfin tunas aggregating around FADs several meters beneath the surface, unlike most of the other seabird species.

In order to have a more precise idea of the real effect of floating aggregating objects like natural logs and anchored or drifting FADs on foraging ecology of seabirds, studies must be conducted in the open ocean, where the occurrence of prey is very patchy.

Acknowledgements. This research was supported by the University of La Réunion (BQR W485). S.J. also benefited from a $\mathrm{PhD}$ grant from the French government. The authors thank Michel Potier and Francis Marsac (IRD, UR Thétis) for their encouragement and help in the field. Marc Taquet, IFREMER La Réunion, kindly provided onboard possibilities during oceanographic cruises. Help from Frederic Ménard (IRD, UR Thétis) with GLM procedures in S-Plus was largely appreciated. S.J. and M.L.C. thank Aurélien Aumjaud and Romain Criou for their help at sea. We thank the captains and crews of the different vessels used. Finally, we thank the 3 anonymous reviewers for their helpful comments on an early draft of the manuscript.

\section{LITERATURE CITED}

Arcos JM, Massuti E, Abello P, Oro D (2000) Fish associated with floating drifting objects as a feeding resource for baleric shearwaters Puffinus mauretanicus during the breeding season. Ornis Fenn 77:177-182

Ashmole NP (1971) Seabird ecology and the marine environment. In: Farner DS, King JR (eds) Avian biology, Vol 1. Academic Press, New York, p 223-286

Ashmole NP, Ashmole MJ (1967) Comparative feeding ecology of seabirds of a tropical oceanic island. Peabody Mus Nat Hist Yale Univ Bull 24:1-131

Au DWK, Pitman RL (1986) Seabird interactions with dolphins and tuna in the eastern tropical Pacific. Condor 88: 304-317

Ballance LT, Pitman RL (1992) Parkinson's petrel distribution and foraging ecology in the eastern Pacific: aspects of an exclusive feeding relationship with dolphins. Condor 94: 825-835

Ballance LT, Pitman RL (1999) Foraging ecology of tropical seabirds. In: Adams NJ, Slotow RH (eds) Proc 22nd Int Ornithol Congr, Durban. Birdlife South Africa, Johannesburg, p 2057-2071

Ballance LT, Pitman RL, Reilly SB (1997) Seabird community structure along a productivity gradient: importance of competition and energetic constraint. Ecology 78:1502-1518

Barré N, Barau A, Jouanin C (1996) Oiseaux de la Réunion, 2nd edn. Edition du Pacifique, Paris

Bräger S (1998) Feeding associations between white-fronted terns and hector's dolphins in New Zealand. Condor 100: 560-562

Brock R (1985) Preliminary study of the feeding habits of pelagic fish around Hawaiian FADs or can FADs enhance local fisheries productivity. Bull Mar Sci 37:40-49

Burger AE (2001) Diving depths of shearwaters. Auk 118: $755-759$

Castro JJ, Santiago JA, Santana-Ortega AT (2002) A general theory on fish aggregation to floating objects: an alternative to the meeting point hypothesis. Rev Fish Biol Fish 11: 255-277

Cayré P (1991) Behaviour of yellowfin tuna (Thunnus albacares) and skipjack tuna (Katsuwonus pelamis) around fish aggregating devices (FADs) in the Comoros Islands as determined by ultrasonic tagging. Aquat Living Resour 4: $1-12$

Clua E, Grosvalet F (2001) Mixed-species feeding aggregation of dolphins, large tunas and seabirds in the Azores. Aquat Living Resour 14:11-18

Conand F (1995) Etude du comportement alimentaire et du comportement de déplacement suivi par marquage acoustique. Commission de l'Océan Indien, Association Thonière Régionale, Victoria, Seychelles

Conand F, Roux O (2000) Feeding habits of the bigeye scad, Selar crumenophthalmus (Carangidae), in La Réunion Island waters (south-western Indian Ocean). Cybium 24: 173-179

Feare CJ (1976) The breeding of sooty tern Sterna fuscata in the Seychelles and the effects of experimental removal of its eggs. J Zool Lond 179:317-360

Flint EN (1991) Time and energy limits to the foraging radius of sooty terns Sterna fuscata. Ibis 133:43-46

Fonteneau A (2000) A worldwide review of purse seine fisheries on FADs. In: Le Gall JY, Cayré P, Taquet M (eds) Pêche thonière et dispositifs de concentration de poissons. IFREMER, Plouzané, p 15-35

Fréon P, Dagorn L (2000) Review of fish associative behaviour: toward a generalisation of the meeting point hypothesis. Rev Fish Biol Fish 10:183-207

Haney JC (1986) Seabird patchiness in tropical oceanic waters: the influence of Sargassum 'reefs'. Auk 103:141-151

Harrison CS, Seki MP (1987) Trophic relationships among tropical seabirds at the Hawaiian Islands. In: Croxall JP (ed) Seabird feeding ecology and role in marine ecosystems. Cambridge University Press, Cambridge

Harrison CS, Hida TS, Seki MP (1983) Hawaiian seabird feeding ecology. Wildl Monogr 85:71

Harrison P (1983) Seabirds: an identification guide. Croome Helm, Beckenham

Hayes FE, Baker WS (1989) Seabird distribution at sea in the Galapagos Islands: environmental correlations and associations with upwelled water. Colon Waterbirds 12:60-66

Heinemann D (1981) A rangefinder for pelagic bird censusing. J Wildl Manag 45:489-493

Hida TS (1970) Surface tuna schools located and fished in equatorial eastern Pacific. Comm Fish Rev 32:34-37

Hoffman W, Heinemann D, Wiens JA (1981) The ecology of seabird feeding flocks in Alaska. Auk 98:437-456

Holland KN, Brill RW, Chang RKC (1990) Horizontal and vertical movements of yellowfin and bigeye tuna associated with fish aggregating devices. Fish Bull 88:493-507

Holland KN, Jaffe A, Cortez W (2000) The fish aggregating 
devices (FAD) system in Hawaii. In: Le Gall JY, Cayré P, Taquet $M$ (eds) Pêche thonière et dispositifs de concentration de poissons. IFREMER, Plouzané, p 55-62

Hulsman K (1988) The structure of seabird communities: an example from australian waters. In: Burger J (ed) Seabirds and other marine vertebrates: competition, predation and other interactions. Columbia University Press, New York

Hunt GLJ (1990) The pelagic distribution of marine birds in a heterogeneous environment. Polar Res 8:43-54

Hunt GLJ (1991) Occurrence of polar seabirds in relation to prey concentrations and oceanographic factors. In: Sakshaug E, Hopkins CCE, Øritsland NA (eds) Pro Mare Symp Polar Marine Ecology, Trondheim. Polar Res 10(2):12-16

Hunt GLJ, Schneider DC (1987) Scale-dependent processes in physical and biological environment of marine birds. In: Croxall JP (ed) Seabirds: feeding biology and role in marine ecosystems. Cambridge University Press, Cambridge, $\mathrm{p} 7-41$

Hunt GLJ, Harrison NM, Hamner WM, Obst BS (1988) Observations of a mixed-species flock of birds foraging on euphausiids near St. Matthew Island, Bering Sea. Auk 105:345-349

Hunt GLJ, Mehlum F, Russell RW, Irons D, Decker MB, Becker PH (1999) Physical processes, prey abundance, and the foraging ecology of seabirds. In: Adams NJ, Slotow R (eds) Proc 22nd Int Ornithol Congr, Durban. BirdLife South Africa, Johannesburg, p 2040-2056

Josse E, Bertrand A, Dagorn L (1999) An acoustic approach to studying tuna aggregated around fish aggregating devices in French Polynesia: methods and validation. Aquat Living Resour 12:303-313

Kakuma S (2000) Synthesis on moored FADs in the north west Pacific region. In: Le Gall JY, Cayré P, Taquet M (eds) Pêche thonière et dispositifs de concentration de poissons. IFREMER, Plouzané, p 63-77

Le Corre M (2001) Breeding seasons of seabirds of Europa Island (southern Mozambique Channel) in relation to seasonal changes in the marine environment. J Zool Lond 254:239-249

Le Corre M, Ghestemme T, Salamolard M, Couzi FX (2003a) Rescue of the mascarene petrel, a critically endangered seabird of Réunion Island, Indian Ocean. Condor 105: 387-392

Le Corre M, Cherel Y, Lagarde F, Lormée H, Jouventin P (2003b) Seasonal and inter-annual variation in the feeding ecology of a tropical oceanic seabird, the red-tailed tropicbird Phaethon rubricauda. Mar Ecol Prog Ser 255: 289-301

MapInfo (1999) MapInfo user's guide. MapInfo, Troy, NY

Marsac F (1992a) Les radars à oiseaux: quels effets en attendre sur l'amélioration des rendements des thoniers? $12^{\mathrm{a}}$ semana des pescas dos Açores, Horta Faial, Portugal, p 235-251

Marsac F (1992b) Etude des relations entre l'hydroclimat et la pêche thonière hauturière tropicale dans l'océan Indien occidental. PhD thesis, Bretagne Occidentale

Marsac F, Cayré P (1998) Telemetry applied to behaviour analysis of yellowfin tuna (Thunnus albacares, Bonnaterre, 1788) movements in a network of fish aggregating devices. Hydrobiologia 371/372:155-171

Mills KL (1998) Multispecies seabird feeding flocks in the Galapagos Islands. Condor 100:277-285

Editorial responsibility: Otto Kinne (Editor), Oldendorf/Luhe, Germany
Parrish JK, Lemberg N, South-Oryshchyn L (1998) Effects of colony location and nekton abundance on the at-sea distribution of four seabird species. Fish Oceanogr 7 : 126-135

Piton B, Taquet M (1992) Océanographie physique des parages de l'île de la Réunion (Océan Indien). Document Scientifique ORSTOM, La Réunion

Pocklington R (1979) An oceanographic interpretation of seabird distributions in the Indian Ocean. Mar Biol 51:9-21

Raya Rey A, Schiavini ACM (2000) Distribution, abundance and associations of seabirds in the Beagle Channel, Tierra del Fuego, Argentina. Polar Biol 23:338-345

Ribic CA, Ainley DG (1997) The relationships of seabird assemblages to physical habitat features in Pacific equatorial waters during spring 1984-1991. ICES J Mar Sci 54:593-599

Ribic CA, Randall D, Hess N, Peake D (1997a) Distribution of seabirds in the northern Gulf of Mexico in relation to mesoscale features: initial observations. ICES J Mar Sci 54:545-551

Ribic CA, Ainley DG, Spear LB (1997b) Seabird associations in Pacific equatorial waters. Ibis 139:482-487

Robertson WB (1969) Trans Atlantic migration of juvenile sooty terns. Nature 223:632-634

Schneider DC, Piatt JF (1986) Scale-dependent correlation of seabirds with schooling fish in a coastal ecosytem. Mar Ecol Prog Ser 32:237-246

Spear LB, Ballance LT, Ainley DG (2001) Response of seabirds to thermal boundaries in the tropical Pacific: the thermocline versus the Equatorial Front. Mar Ecol Prog Ser 219: 275-289

S-Plus (2001) S-Plus 6 for Windows, user's guide. Insightful, Seattle

Stahl JC, Bartle JA (1991) Distribution, abundance and aspects of the pelagic ecology of Barau's petrel (Pterodroma baraui) in the south-west Indian Ocean. Notornis 38:211-225

Statsoft (1995) Statistica Guide de l'utilisateur. Statsoft, Tulsa, OK

Surman CA, Wooller RD (2003) Comparative feeding ecology of five sympatric terns at a sub-tropical island in the eastern Indian Ocean. J Zool Lond 259:219-230

Tasker ML, Hope Jones P, Dixon T, Blake BF (1984) Counting seabirds at sea from ships: a review of methods employed and a suggestion for a standardized approach. Auk 101: $567-577$

Tessier E, Poisson F (1997) Bilan sur la mise en place d'un système de récolte de données sur la pêche artisanale sur DCP. Report No. 34. Commission de l'Océan Indien, Association Thonière Régionale, Victoria, Seychelles

Tessier E, Rey-Valette H, Ah-Nième D, Bargain RM, Venkatassamy A, Wendling B (2000) Halieutic systems and FADs in the Indian Ocean: a review of the various trials carried out and results obtained in term of integration and overall benefits. In: Le Gall JY, Cayré P, Taquet M (eds) Pêche thonière et dispositifs de concentration de poissons. IFREMER, Plouzané, p 159-183

Van Den Berg AB, Smeenk C, Bosman CAW, Haase BJM, Van Der Niet AM, Cadée GC (1990) Barau's petrel Pterodroma baraui, Jouanin's petrel Bulweria fallax and other seabirds in the northern Indian Ocean in June-July 1984 and 1985. Ardea 79:1-14

Veit RR, Hunt GLJ (1992) The spatial dispersion of seabirds near the South Orkney Islands and the Weddell-Scotia confluence. Polar Biol 11:637-641

Submitted: July 4, 2003; Accepted: December 9, 2003

Proofs received from author(s): February 12, 2004 